Chapter 10

\title{
Biodegradation in Animal Manure Management
}

\author{
Matthieu Girard, Joahnn H. Palacios, Martin Belzile, \\ Stéphane Godbout and Frédéric Pelletier
}

Additional information is available at the end of the chapter

http://dx.doi.org/10.5772/56151

\section{Introduction}

Typical manure management strategies from intensive livestock feeding operations in Canada include the pre-storage of manure inside the animal buildings, long-term storage at the farm and finally field application of manure as fertilizer. Different biodegradation phenomena can occur in each of these steps, but naturally occurring biodegradation can cause harmful emissions. However, when used properly, biodegradation can also be beneficial and reduce pollution from animal wastes. This chapter will describe in detail the different processes involved in the biodegradation of manure, the emissions that are produced as well as how biodegradation can be used to treat both the manure and the emissions from manure management. The phenomena and systems described here can be applied to most livestock feeding operations (dairy and beef cattle, poultry, egg production, hog, etc.), but the specific examples and results will be provided for the swine industry.

\section{Phenomena}

\subsection{Manure composition}

Manure from animal husbandry contains a wide range of compounds that can be used by microorganisms for energy requirements or anabolic processes. In general, manure contains organic matter, nitrogen, phosphorous and potassium as well as numerous micronutrients (sulphur, copper and zinc for example). The specific concentrations of these components may vary according to several factors: building and storage management as well as the genetics of the animals, their growth stage and their diet. For example, experience has shown that hog diets supplemented with phytase had the effect of, among others, reducing the release of 
phosphorus in manure. Manure composition may also vary with water dilution when using water-saving drinkers in the building or a roof structure to cover the manure storage pit for example.

According to results from the analysis of various types of manure carried out by the Research and Development Institute for the Agri-Environment (IRDA), the typical swine manure composition for maternity, nursery and growing-finishing stages can be represented by the average values found in Table 1 [1]. The main difference between growth stages is related to the dry matter content. Indeed, manure produced by grower-finisher pigs is generally dryer and therefore more concentrated in nutrients.

\begin{tabular}{ccccc}
\hline Parameter & Unit & \multicolumn{3}{c}{ Growth stage } \\
\hline & & Maternity & Nursery & Growing-finishing \\
\hline Dry matter & $\%$ & 1.8 & 2.7 & 4.7 \\
\hline Total nitrogen & $\%$ & 0.2 & 0.3 & 0.6 \\
\hline Ammonium nitrogen & $\mathrm{mg} / \mathrm{kg}$ & 1488 & 1545 & 2846 \\
\hline Phosphorus & $\mathrm{mg} / \mathrm{kg}$ & 593 & 762 & 1690 \\
\hline Potassium & $\mathrm{mg} / \mathrm{kg}$ & 1049 & 1964 & 3405 \\
\hline Copper & $\mathrm{mg} / \mathrm{kg}$ & 8.9 & 29.6 & 49.9 \\
\hline Zinc & $\mathrm{mg} / \mathrm{kg}$ & 41.0 & 208.7 & 82.9 \\
\hline Manganese & $\mathrm{mg} / \mathrm{kg}$ & 10.3 & 14.9 & 29.85 \\
\hline Calcium & $\mathrm{mg} / \mathrm{kg}$ & 697 & 701 & 1700 \\
\hline Magnesium & $\mathrm{mg} / \mathrm{kg}$ & 213 & 311 & 674
\end{tabular}

Table 1. Typical composition of swine manure for each growth stage (adapted from [1])

To provide a full description of manure composition, values for organic matter must also be considered. For swine manure, values of 19 to $51 \mathrm{gO}_{2} / \mathrm{L}$ as COD (chemical oxygen demand) are normally encountered [2,3]. The organic matter content depends essentially on the type of feed, manure management and manure age. After excretion, manure decomposes naturally; suspended solids contained in the manure are hydrolyzed into dissolved elements and biodegradation by microorganisms occurs. This decomposition of manure may be favored by appropriate conditions which depend on the proportion of elements contained in the slurry, the amount of oxygen, the $\mathrm{pH}$ and the temperature.

\subsection{Aerobic biodegradation}

Different microorganisms can grow by using various compounds found in manure both in the presence and in the absence of oxygen. The microorganisms can also be classified according to the compounds consumed.

Organic matter represents an important fraction of swine manure and includes many compounds that can be separated in four fractions: readily biodegradable $\left(\mathrm{S}_{\mathrm{S}}\right)$, slowly biodegradable $\left(X_{S}\right)$, inert soluble $\left(S_{I}\right)$ and inert particulate $\left(X_{I}\right)$. When considering biodegradation, only 
the biodegradable fractions $\left(S_{S}\right.$ and $\left.X_{S}\right)$ are taken into account. The $S_{S}$ fraction is usually in soluble form and is composed of relatively small molecules such as volatile fatty acids (acetic, butyric and valeric acids), monosaccharides (sugar) and alcohols [3]. On the other hand, the $X_{S}$ fraction is usually found as particles and is composed of high molecular weight organic polymers or dead biomass. This fraction of the organic matter cannot be directly assimilated by microorganisms and must first be hydrolyzed to $S_{\mathrm{S}}$. The distribution of the organic matter can be quite variable among the different fractions and depends on many factors such as the type of feed and the manure storage time. For the $S_{S}$ fraction, values from the literature vary from 8 to $30 \%$ of the total COD, from 30 to $60 \%$ for the $X_{S}$ and from 10 to $60 \%$ for the inert fractions $\left(S_{I}\right.$ and $\left.X_{I}\right)$ [2-4]. Various types of microorganisms can degrade organic matter: bacteria, protozoa and fungi. As shown in equation 1, these microorganisms degrade the organic matter and release carbon dioxide $\left(\mathrm{CO}_{2}\right)$, water and biomass:

$$
\text { Organic matter }+\mathrm{O}_{2}+\text { Nutrients } \rightarrow \text { Biomass }+\mathrm{CO}_{2}+\mathrm{H}_{2} \mathrm{O}
$$

Nitrogen in manure can be found as ammonium $\left(\mathrm{NH}_{4}{ }^{+}\right)$, trapped in organic molecules or as urea. Both the organic nitrogen and the urea must be broken down into $\mathrm{NH}_{4}{ }^{+}$by microorganisms before they can be accessible. The aerobic oxidation of $\mathrm{NH}_{4}{ }^{+}$, nitrification, follows two distinct steps: the transformation of $\mathrm{NH}_{4}{ }^{+}$into nitrite $\left(\mathrm{NO}_{2}{ }^{-}\right)$by Nitroso bacteria (Nitrosomonas for example) followed by the oxidation to nitrate $\left(\mathrm{NO}_{3}^{-}\right)$performed by Nitro bacteria (Nitrobacter for example) [5]. The relative kinetics between the two steps are controlled by the temperature and will determine which compound is accumulated $\left(\mathrm{NO}_{2}{ }^{-}\right.$or $\left.\mathrm{NO}_{3}^{-}\right)$. The two separate steps of the nitrification reaction are presented in equations 2 and 3 while the combined reaction is given in equation 4 [6]:

$$
\begin{gathered}
\mathrm{NH}_{4}{ }^{+}+3 / 2 \mathrm{O}_{2} \rightarrow \mathrm{NO}_{2}{ }^{-}+2 \mathrm{H}_{2}+\mathrm{H}_{2} \mathrm{O} \\
\mathrm{NO}_{2}^{-}+1 / 2 \mathrm{O}_{2} \rightarrow \mathrm{NO}_{3}^{-} \\
\mathrm{NH}_{4}^{+}+2 \mathrm{O}_{2} \rightarrow \mathrm{NO}_{3}^{-}+2 \mathrm{H}_{2}+\mathrm{H}_{2} \mathrm{O}
\end{gathered}
$$

Regarding the other compounds in manure (phosphorous, potassium and heavy metals), they can used by microorganisms for different microbiological processes or to synthesise certain compounds such as DNA and amino acids.

\subsection{Anaerobic biodegradation}

Without oxygen present, (e.g. when all the dissolved oxygen has been exhausted by aerobic respiration) several compounds are released by the anaerobic metabolism of microorganisms still utilizing nutrients in manure. By a complex series of reactions, the anaerobic 
biodegradation of manure produces different gases, mainly methane $\left(\mathrm{CH}_{4}\right)$, hydrogen sulfide $\left(\mathrm{H}_{2} \mathrm{~S}\right)$, ammonia $\left(\mathrm{NH}_{3}\right)$ and $\mathrm{CO}_{2}$, as well as many intermediate compounds; the most noteworthy are volatile fatty acids and other odorous molecules. A study from the North Carolina State University identified a total of 331 compounds that cause odours from manure [7].

Biological decomposition during storage or during anaerobic digestion contributes to the transfer of nutrients, especially nitrogen and phosphorus, between different fractions and chemical forms in manure [8]. For nitrogen, anaerobic digestion can break down organic nitrogen and produce $\mathrm{NH}_{4}{ }^{+}$and $\mathrm{NH}_{3}$. If oxidised nitrogen compounds $\left(\mathrm{NO}_{2}{ }^{-}\right.$or $\left.\mathrm{NO}_{3}{ }^{-}\right)$are present, heterotrophic microorganisms can use these compounds as an electron acceptor and produce nitrogen gas $\left(\mathrm{N}_{2}\right)$. This process is called denitrification and requires a source of easily biodegradable organic carbon. It can also produce nitrous oxide $\left(\mathrm{N}_{2} \mathrm{O}\right)$, a potent greenhouse gas, as a by-product. For phosphorus, anaerobic digestion contributes to moving some of the dissolved portion into the bodies of bacteria that carry out the anaerobic digestion process. All of the phosphorous present in the manure will still be present in the digester sludge [9]. Anaerobic digestion may also change the $\mathrm{pH}$ and the chemical form of salts and metals, such as iron, calcium and magnesium, which may affect the amount of suspended phosphates as a result of precipitation processes [8].

There is a huge interest in controlling anaerobic biodegradation for bioenergy production purposes. In fact, the anaerobic digestion of manure in an airtight container, under certain conditions, will form biogas, an energy source composed of a mixture of $\mathrm{CH}_{4}, \mathrm{CO}_{2}$ and trace amounts of other gases. Anaerobic digestion is a multi-stage process (Figure 1). Communities of hydrolytic bacteria break down complex organic matter from manure to simpler compounds (sugars, amino acids and fatty acids). Then, acid forming bacteria convert the simple compounds to alcohols and carbon acids (volatile fatty acids), as well as hydrogen, $\mathrm{CO}_{2}, \mathrm{NH}_{3}$, $\mathrm{NH}_{4}{ }^{+}$and $\mathrm{H}_{2} \mathrm{~S}$ [10]. An amount of acetic acid is also produced at this stage, which along with hydrogen, can be used directly by methanogens. Other molecules, such as volatile fatty acids must first be catabolised to produce acetic acid, as well as $\mathrm{CO}_{2}$ and $\mathrm{H}_{2}$ that can be directly used by methanogens.

\section{Biodegradation as a source of emissions}

\subsection{Buildings}

Biodegradation processes begin before manure is even expelled from the animals. Intestinal microorganisms anaerobically degrade nutrients as they pass through an animal's digestive system. Once expelled, manure comes in contact with oxygen and aerobic microorganisms can become dominant after several hours. However, most animal housing systems use some sort of pre-storage for the manure inside the barn where anaerobic conditions can once again take over. Emissions from biodegradation of manure inside animal buildings are therefore a mix of anaerobic and aerobic products and are removed by the ventilation air. The emission rates 


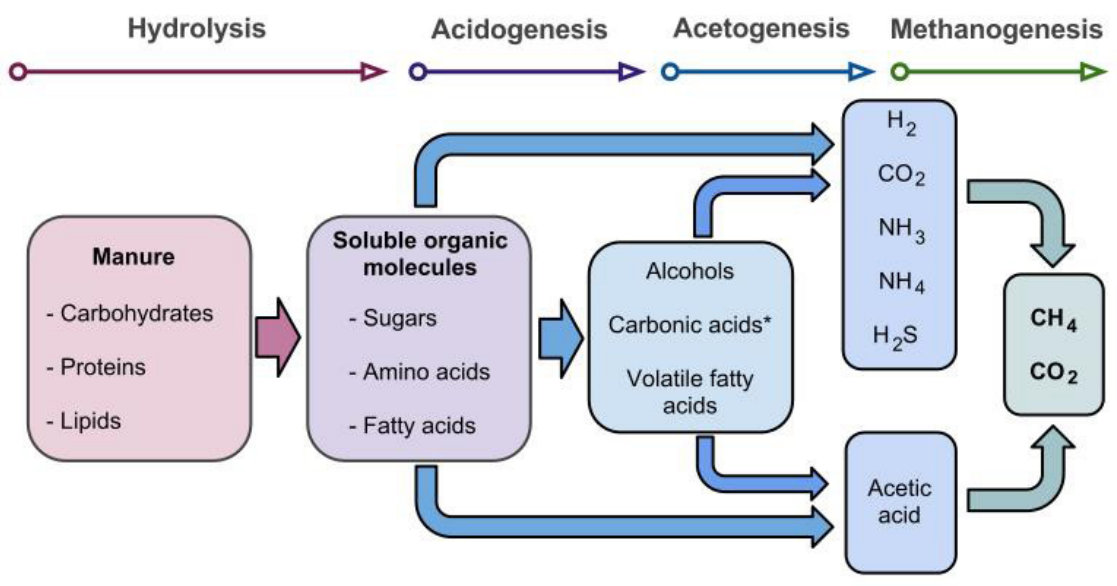

Figure 1. Process stages of anaerobic digestion (Modified from [10])

are affected by many factors such as ventilation flow rate, temperature, manure separation systems and animal activity among others.

Emissions from pig barns include a number of gases $\left(\mathrm{CO}_{2}, \mathrm{CH}_{4}\right.$, and $\left.\mathrm{N}_{2} \mathrm{O}\right)$, dust particles (inhalable and breathable), bioaerosols (bacteria, viruses, endotoxins and fungi) and several other volatile compounds such as $\mathrm{NH}_{3}$ and $\mathrm{H}_{2} \mathrm{~S}$. In addition, an increasing importance is given to the odour nuisance associated with swine production. Thus, research in this area has become more important in recent years.

A baseline emission scenario of swine buildings was defined by [11] based on an inventory of gas, odour and dust emission data (Table 2). The resulting scenario provides a good overview of the magnitude of the emissions that are produced in swine production systems for the different growth stages (maternity, nursery and growing-finishing).

Odours, consisting of a complex mixture of several chemical compounds, are one of the major concerns in the emissions from the swine sector. Odours are expelled from barns by the ventilation system at 2.5 to $51.6 \mathrm{EOU} / \mathrm{s} /$ pig (EOU: European Odour Unit), depending on the growth stage. According to data, the nursery stage tends to emit fewer odours than the other stages. The use of odour reduction technologies in animal buildings, such as air cleaning technologies, could reduce the level of nuisance. In fact, downwind odours from confined feeding operations are considered to be a nuisance that may lead to a reduced quality of life by nearby residents.

$\mathrm{NH}_{3}$ is produced by the degradation of urea in the urine on floors or still stored in the building. In a swine barn, average emissions range from 0.33 to $14 \mathrm{gNH}_{3} / \mathrm{d} / \mathrm{pig}$ depending on the growth stage (Table 2). The rate of $\mathrm{NH}_{3}$ emissions from buildings, storage structures and land spreading is favored when the liquid and solid fractions of the manure are not separated and 


\begin{tabular}{|c|c|c|c|c|}
\hline \multirow{2}{*}{ Parameter } & \multirow{2}{*}{ Unit } & \multicolumn{3}{|c|}{ Growth stage } \\
\hline & & Maternity & Nursery & Growing-finishing \\
\hline & & \multicolumn{3}{|c|}{ Europe } \\
\hline Odours & EOU/s/pig & $21.2(16.3)$ & $10.69(8.05)$ & $13.75(8.23)$ \\
\hline $\mathrm{NH}_{3}$ & $\mathrm{~g} / \mathrm{d} / \mathrm{pig}$ & $14.2(2.9)$ & $0.94(0.85)$ & $7.75(4.95)$ \\
\hline $\mathrm{CH}_{4}$ & $\mathrm{~g} / \mathrm{d} / \mathrm{pig}$ & 57.7 & 10.7 & $12.42(10.41)$ \\
\hline $\mathrm{CO}_{2}$ & $\mathrm{~kg} / \mathrm{d} / \mathrm{pig}$ & - & - & $2.25(087)$ \\
\hline $\mathrm{N}_{2} \mathrm{O}$ & $\mathrm{g} / \mathrm{d} / \mathrm{pig}$ & - & - & $2.72(3.26)$ \\
\hline $\mathrm{PM}_{2,5}$ & $\mathrm{mg} / \mathrm{h} / \mathrm{pig}$ & - & 6.4 & 6.9 \\
\hline $\mathrm{PM}_{10}$ & $\mathrm{mg} / \mathrm{h} / \mathrm{pig}$ & $8.2(2.55)$ & - & $4.71(2.50)$ \\
\hline \multirow[t]{2}{*}{$\mathrm{PM}_{\text {total }}$} & $\mathrm{mg} / \mathrm{h} / \mathrm{pig}$ & 50 & - & - \\
\hline & & \multicolumn{3}{|c|}{ Canada } \\
\hline Odours & EOU/s/pig & $51.56(53.45)$ & $2.5(0.69)$ & $7.82(8.19)$ \\
\hline $\mathrm{NH}_{3}$ & $\mathrm{~g} / \mathrm{d} / \mathrm{pig}$ & - & $0.33(0.14)$ & - \\
\hline$\overline{\mathrm{CH}_{4}}$ & $\mathrm{~g} / \mathrm{d} / \mathrm{pig}$ & $59.9(45.13)$ & $1.45(2.37)$ & $3.78(3.76)$ \\
\hline $\mathrm{CO}_{2}$ & $\mathrm{~kg} / \mathrm{d} / \mathrm{pig}$ & $5,29(2,26)$ & $0,55(0,003)$ & $1,71(1,21)$ \\
\hline $\mathrm{N}_{2} \mathrm{O}$ & g/d/pig & 0,0 & $0,007(0,005)$ & $0,04(0,04)$ \\
\hline $\mathrm{PM}_{2.5}$ & $\mathrm{mg} / \mathrm{h} / \mathrm{pig}$ & - & - & - \\
\hline $\mathrm{PM}_{10}$ & $\mathrm{mg} / \mathrm{h} / \mathrm{pig}$ & - & - & - \\
\hline $\mathrm{PM}_{\text {total }}$ & $\mathrm{mg} / \mathrm{h} / \mathrm{pig}$ & - & - & $63(4,12)$ \\
\hline
\end{tabular}

Confidence intervals in parentheses.

EOU : European odour unit

$\mathrm{PM}_{2,5} ; \mathrm{PM}_{10}$ and $\mathrm{PM}_{\text {total }}$ : particle matter smaller than 2.5, 10 and 100 micrometers respectively.

Table 2. Emissions scenario from swine buildings for different growth stages (adapted from [11])

when the manure: contains nitrogen from undigested food, has a high $\mathrm{pH}$ and has a high temperature. Moreover, a high contact area between the air and the manure as well as a high air movement at the surface increase $\mathrm{NH}_{3}$ emissions.

In animal production, $\mathrm{CH}_{4}$ comes from two sources, enteric fermentation in ruminants (cellulose digestion) and the decomposition of manure under anaerobic conditions. In the case of pig production, only the second source applies. At the building, where waste is handled in solid form in aerobic conditions, the production of $\mathrm{CH}_{4}$ is minimal. Under anaerobic conditions, the production of $\mathrm{CH}_{4}$ varies with the temperature and the composition of the manure. The emissions inventoried in Table 2 suggest that $\mathrm{CH}_{4}$ is emitted from swine barns at 1.45 to $57.7 \mathrm{~g} / \mathrm{d} / \mathrm{pig}$, with higher values at the maternity stage. The concern of $\mathrm{CH}_{4}$ emissions from 
animal production systems is due to its high potential as a greenhouse gas and by the large quantities produced.

$\mathrm{CO}_{2}$, produced by the metabolism of animals, is the most prominent gas in animal housing. Almost all $\mathrm{CO}_{2}(96 \%)$ is produced by the respiration of animals; the rest comes from the decomposition of manure [12] and the combustion gases from heating systems. [13] showed that $\mathrm{CO}_{2}$ emissions from pig manure can be estimated by multiplying the $\mathrm{CH}_{4}$ emissions by a factor of $1.42 \mathrm{~kg} \mathrm{CO}_{2}$ per kilogram of $\mathrm{CH}_{4}$.

$\mathrm{N}_{2} \mathrm{O}$ emissions are not as high as the other gases expelled from animal buildings. For instance, according to Table 2, the maximal average $\mathrm{N}_{2} \mathrm{O}$ emission was $2.7 \mathrm{~g} / \mathrm{d} / \mathrm{pig}$. However, $\mathrm{N}_{2} \mathrm{O}$ is also a major greenhouse gas and air pollutant. Considered over a 100-year period, it has 298 times more impact on climate change than $\mathrm{CO}_{2}$ [14]. The formation of $\mathrm{N}_{2} \mathrm{O}$ occurs during the processes of nitrification and denitrification over the course of manure management. In fact, it is during denitrification that $\mathrm{N}_{2} \mathrm{O}$ is emitted, but to do so, nitrification must first take place. Under anoxic conditions, there is not enough oxygen for microorganisms who will take the oxygen they need from $\mathrm{NO}_{3}{ }^{-}$. Thus, the $\mathrm{NO}_{3}{ }^{-}$is then reduced to $\mathrm{N}_{2}$. However, when the reaction is not complete (e.g. due to process kinetics or the sudden presence of dissolved oxygen), $\mathrm{N}_{2} \mathrm{O}$ is emitted. It should be noted that this cannot occur under complete anaerobic conditions, since these microorganisms cannot survive.

The Environmental Protection Agency of the United States [15] defines particulate matter as a complex mixture of extremely small particles and liquid droplets. Moreover, according to [16], suspended particles in livestock buildings differ from other types of particles for three reasons: their concentration is usually 10 to 100 times greater than other indoor environments, they are vectors of odours and gases and they are biologically active, usually containing a wide variety of bacteria and microorganisms. The dust concentration in the air of buildings depends on several factors, such as relative humidity, temperature, level of animal activity, type and mode of feeding and presence of litter. Such particles have a significant impact on the health and well-being of both workers and animals. The consequences are mainly related to respiratory problems. However, in the inventory performed by [11] (Table 2), particular matter (PM) is the least documented parameter.

\subsection{Storage}

During manure storage, aerobic conditions are present at the surface of the manure, but after a shallow depth, anaerobic conditions prevail. Emissions from manure storage generally represent the intermediate and end products of anaerobic digestion: $\mathrm{NH}_{3}, \mathrm{CH}_{4}, \mathrm{CO}_{2}, \mathrm{H}_{2} \mathrm{~S}$ and odours. The composition of the manure as well as the storage and weather conditions (temperature, $\mathrm{pH}$, precipitation and wind) can affect the biodegradation of manure and will dictate the emission rates for each compound.

Typical gas emissions at the surface of manure tanks have been measured in the past using a special device. A sampling chamber, developed at IRDA, floats on the storage tank and takes gas samples in a confined space, swept by an airflow of $100 \mathrm{~L} / \mathrm{min}$. The gas concentrations are measured at the outlet of the chamber and the increase of the concentration compared to the 
ambient air is attributed to the emitting surface. A photo of the sample chamber floating on a manure storage tank is shown in Figure 2.

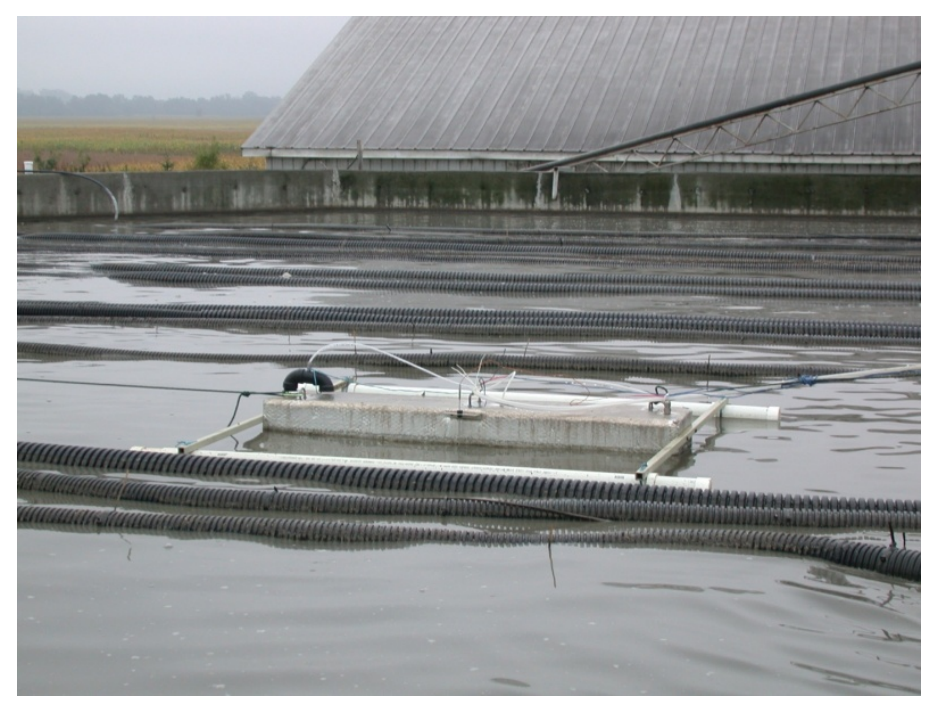

Figure 2. IRDA sampling device on a manure storage tank

Various research projects have been carried out using this instrument. Typical values for $\mathrm{CH}_{4}$ $\mathrm{CO}_{2}$ and $\mathrm{N}_{2} \mathrm{O}$ are found in Table 3 . Annual emissions represent the summation of the emissions over one year while daily averaged values represent this value distributed on a daily basis and the maximal daily values is the highest emission over one day during the year.

\begin{tabular}{llccc}
\hline \multirow{2}{*}{ Parameter } & Units & \multicolumn{3}{c}{ Gas } \\
\cline { 3 - 5 } & & $\mathbf{C H}_{\mathbf{4}}$ & $\mathbf{C O}_{\mathbf{2}}$ & $\mathbf{N H}_{\mathbf{3}}$ \\
\hline Annual emissions & $\mathrm{g} /$ year $/ \mathrm{m}^{2}$ & 7940 & 19096 & 530 \\
\hline Daily mean values & $\mathrm{g} /$ day $/ \mathrm{m}^{2}$ & 22 & 52 & 1.5 \\
\hline Maximal daily values & $\mathrm{g} /$ day $/ \mathrm{m}^{2}$ & 134 & 2662 & 6.0 \\
\hline
\end{tabular}

Table 3. Gas concentrations from swine manure storage tanks

Generally, no $\mathrm{N}_{2} \mathrm{O}$ is produced during swine manure storage [17] since anaerobic conditions prevail and the $\mathrm{NH}_{4}{ }^{+}$cannot be oxidized to $\mathrm{NO}_{3} \cdot \mathrm{N}_{2} \mathrm{O}$ is essentially generated once the slurry has been applied to agricultural land as a fertilizer where both aerobic and anoxic conditions can exist [18]. 


\subsection{Fields}

Measuring field emissions is a complex area of research and finding representative data for the phenomena which occur after manure application represents a challenge. That is why this section contains only an overview of data measured by different research groups.

Once manure has been applied to agricultural land as a fertilizer, microorganisms continue to degrade it and release additional compounds. Anaerobic conditions can remain for a short time after manure has been applied; therefore $\mathrm{NH}_{3}, \mathrm{CH}_{4}, \mathrm{H}_{2} \mathrm{~S}$ and odours are emitted directly following application. Other compounds, such as $\mathrm{N}_{2} \mathrm{O}$, require the combination of aerobic and anaerobic processes and can be produced for a long time after manure application. Certain field emissions ( $\mathrm{NH}_{3}$ and odours mainly) can be reduced by quickly incorporating manure into soil after application. Factors that influence these reactions are soil $\mathrm{pH}$, exchange capacity and weather condition. It is therefore difficult to present typical values of gas emissions. An example of $\mathrm{NH}_{3}$ emissions is however presented in Figure 3; emissions are presented on a daily basis following manure application.

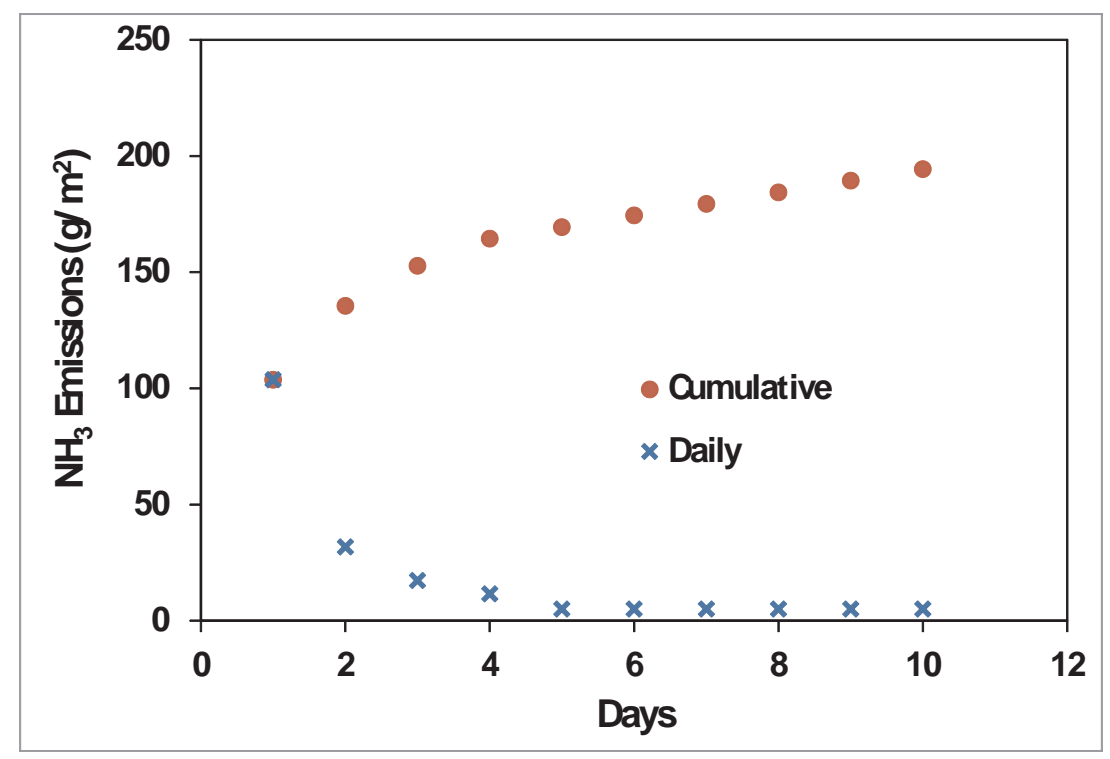

Figure 3. Gases emissions from the field fallowing application of manure (Adapted from [19])

Regarding the production of $\mathrm{N}_{2} \mathrm{O}$, emission values vary greatly. For example, cumulative values measured by [20] for a clay soil cultivated with silage corn varied between 0.255 and $0.873 \mathrm{~g} / \mathrm{m}^{2}$ for the entire growing season (May to October). Although it is only one example, it demonstrates the variation in the measurement of $\mathrm{N}_{2} \mathrm{O}$ whereas several factors such as soil type and culture remained constant. 


\section{Biodegradation as treatment}

\subsection{Manure}

Natural biodegradation phenomena in animal manure can cause harmful emissions, but certain biological processes, whether anaerobic or aerobic, can be used to treat manure. Aerobic biological processes for manure treatment can be relatively simple as in short-term manure aeration, which can remove up to $90 \%$ of the biodegradable organic compounds. This process can also significantly reduce odours (up to $96 \%$ as evaluated with volatile fatty acids) during manure storage for up to 190 days [21]. Biological processes using suspended biomass, such as aerated lagoons and activated sludge reactors developed for wastewater treatment, can be applied to treat manure [22]. Bioreactors using biomass fixed on a porous filter material can also be used to treat manure, but the solids must be removed prior to treatment in order to avoid clogging problems. The manure can be supplied to these systems from the bottom to obtain a submerged upflow system or from the top and trickle down the filter bed.

Laboratory-scale tests using upflow aerated biological filters showed good results for manure treatment: removal efficiencies of $88 \%$ for biodegradable organic matter and $94 \%$ for $\mathrm{NH}_{4}{ }^{+}$ with two $1.5 \mathrm{~m}^{3}$ biofilters treating $8 \mathrm{~m}^{3} / \mathrm{d}$ of flushed swine manure [23]. In another study, part of the effluent was recirculated to an anoxic reactor at the beginning of the process for complete nitrogen removal [24]. The bioreactor removed $72 \%$ of the organic matter as COD, $94 \%$ of the $\mathrm{NH}_{4}{ }^{+}$as well as achieving a denitrification rate of $92 \%$. This type of upflow biofilter is available commercially under the name Ekokan ${ }^{\circledR}$ Biofiltration Treatment System and removes between 90 and $98 \%$ of the $\mathrm{NH}_{4}{ }^{+}$and between 40 and $70 \%$ of the biodegradable organic carbon from swine slurry pre-treated to remove solids [25]. The main disadvantage with this type of system is that the filter bed must be regularly backwashed to remove excess biomass.

In a trickling biofilter, the manure is supplied at the top and flows down through the filter bed. Trickling biofilters have been used for almost 100 years for wastewater treatment [5], but they have only recently been applied to manure treatment. Trickling biofilters can be quite simple consisting of a pile of filter material with passive aeration. However, the performance can be limited; results from preliminary tests showed removal efficiencies up to $56 \%$ for biodegradable organic matter and $\mathrm{NH}_{4}{ }^{+}$[26]. Researchers in Québec (Canada) developed a highly engineered system using an enclosed biofilter with forced aeration, the Biosor ${ }^{\circledR}$ biofilter [27]. This type of system can provide a better performance with removal efficiencies up to $99 \%$ for the biodegradable organic matter and above $95 \%$ for the $\mathrm{NH}_{4}{ }^{+}[28,29]$. Furthermore, a study on the nitrogen elimination mechanisms demonstrated that trickling biofilters can achieve simultaneous nitrification and denitrification which transforms the $\mathrm{NH}_{4}{ }^{+}$directly to $\mathrm{N}_{2}$ in one system [30]. By means of a mass balance, it was shown that $30 \%$ of the nitrogen was eliminated as $\mathrm{N}_{2}$ and $10 \%$ as $\mathrm{N}_{2} \mathrm{O}$. For swine manure, loading rates between 0.017 and $0.035 \mathrm{~m}^{3} / \mathrm{m}^{2} / \mathrm{d}$ are generally recommended to avoid clogging problems [29,31]. Due to the high concentrations of nutrients in manure, these values are up to 2000 times lower than the loading rates recommended for wastewater treatment. 
While biofiltration can be used to treat liquid manure, composting is a biological system that can treat solid materials to produce a biologically stable product rich in humic compounds [22]. In addition, composting can reach relatively high temperatures $\left(40-60^{\circ} \mathrm{C}\right)$ which can reduce pathogenic microorganisms by up to $92 \%$ and improve the sanitary quality of the fertilizer produced [32]. Since swine manure is generally managed in liquid form, bulking agents must be added. These additives generally have a high carbon content, such as straw or sawdust, in order to improve the carbon to nitrogen mass ratio of the composting mix. A mass ratio between 25 and 30 is optimal, but values between 15 and 20 can be used to reduce bulking agent requirements. However, this increases reaction time by $30 \%[33,34]$. A major disadvantage of composting is the loss of nitrogen, $10 \%$ as $\mathrm{NH}_{3}$ and $3 \%$ as $\mathrm{N}_{2} \mathrm{O}$ on average according to [35], which reduces the quality of the fertilizer. Since $\mathrm{N}_{2} \mathrm{O}$ is a powerful greenhouse gas, emissions are particularly troubling. By adding nitrite-oxidizing bacteria, [36] were able to reduce $\mathrm{N}_{2} \mathrm{O}$ emissions by $80 \%$.

Aerobic bioreactors are usually operated at ambient temperatures with mesophilic microorganisms to maintain low operating costs, but reactors using a thermophilic biomass at temperatures between 50 and $75^{\circ} \mathrm{C}$ offer interesting advantages. This type of system reduces the quantity of pathogenic microorganisms to improve the sanitary quality of the manure. Furthermore, since nitrification ceases above $40^{\circ} \mathrm{C}$, the nitrogen in manure is retained as $\mathrm{NH}_{4}{ }^{+}[37]$.

As previously described, anaerobic digestion can be used to treat manure and produce biogas for heat or energy requirements. This process also produces a good quality liquid fertilizer since nitrogen is mainly retained in the liquid. However, the nitrogen in the digestate (liquid effluent of the digester) is mainly $\mathrm{NH}_{4}{ }^{+}$[38] and steps must be taken to reduce $\mathrm{NH}_{3}$ losses (cover for storage reservoir, incorporation of digestate in soil after spreading, etc.). Manure can be fed to a digester either in batch, steady-state or semi-continuous modes. Batch systems are the simplest systems technically, but biogas production is irregular over time and the reaction rate is temperature dependant. Continuous systems are more complex, but provide consistent biogas production. Several parameters must be controlled for proper digester operation [39]:

- $\mathrm{pH}$ (between 6.8 and 7.4)

- dry matter content (maximum value of $14 \%$ for proper operation)

- $\mathrm{NH}_{4}{ }^{+}$concentration (must be kept below $3 \mathrm{~g} / \mathrm{L}$ to avoid inhibiting microorganisms)

- carbon to nitrogen ratio (helps optimise process and reduce reaction time).

A disadvantage specific to anaerobic digesters is the $\mathrm{H}_{2} \mathrm{~S}$ produced as a by-product which must generally be removed from the biogas to avoid deteriorating equipment.

\subsection{Gaseous emissions}

Biological treatment systems can also be used to treat gaseous emissions $\left(\mathrm{NH}_{3}, \mathrm{H}_{2} \mathrm{~S}\right.$, greenhouse gases and odours) from manure management in order to improve air quality. Biological 
treatment of air is based on the capacity of microorganisms to transform organic and inorganic pollutants into non-toxic, odour free compounds.

Biological air treatment units (bioreactors) are an established technology, but research is ongoing for new media and reactor designs, microbial structure analysis and modeling of gas compounds removal [40]. Bioreactors can be used for reducing toxic VOC (volatile organic compound) emissions from industrial sources, but in agricultural applications, pollutant concentrations are lower and bioreactors must be simple, easy to operate and maintain and must meet investment and operating costs below those of the industrial sector.

[40-46] conducted detailed analyses from literature reviews providing interesting information on biological methods for air treatment: classification of biological reactors, analysis of the mechanisms involved in biological treatment, design of bioreactors and performance analysis.

The basic mechanisms for the biodegradation of pollutants are the same for all biological treatment systems: the contaminant is absorbed from the gas phase (contaminated air) to a liquid phase where biological degradation is initiated. For organic contaminants, oxidation reactions (and sometimes reductions) transform the contaminant in a mixture of $\mathrm{CO}_{2}$, water vapour and biomass. The air pollutants (organic or inorganic) are used as a source of energy and/or carbon for the development of the microbial population. There are three types of bioreactors with different configurations, which can be used to achieve the transfer between the gas and the liquid phases and promote the microbial metabolic reactions: biofilters, biotrickling filters and bioscrubbers. Such equipment differ by the nature of the microbiological phase (microorganisms attached to the filter bed or suspended in the liquid) and by the circulation mode of the liquid (stationary or flowing) (Table 4).

\begin{tabular}{lll}
\hline Reactor & Microorganisms & Liquid phase \\
\hline Biofilter & Fixed & Stationary \\
\hline Biotrickling filter & Fixed & Flowing \\
\hline Bioscrubber & Suspended & Flowing \\
\hline
\end{tabular}

Table 4. Classification of biological reactors for air treatment [47].

\subsection{Biofilters}

Biofiltration is the oldest and most widespread biotechnology for the treatment of gaseous emissions. The contaminated gases flow through a humid porous material, usually made of organic waste, where microorganisms capable of degrading the pollutants are present [48]. The microorganisms will grow attached to the material, thereby forming a wet biofilm wherein the air pollutants are absorbed and then degraded by the microorganisms. A liquid nutrient solution can be sprayed periodically over the filter bed to maintain proper moisture levels and to supplement certain nutrients if necessary. The moisture content of the filtration equipment and the maintenance of the biofilm are essential elements for maintaining the performance of this biological reactor. If a biofilter is not irrigated, moisture should be controlled by the 
humidity of the air fed to the device. This type of control on the moisture content of the filter media is not always effective and the variations in the humidity and temperature of the incoming air can affect the performance of the biofilter [41]. The filter material can also lose its porosity with time; it can even become clogged by excess biomass growth.

The most common type of biofilter is the open biofilter (Figure 4). This equipment can be exposed to atmospheric conditions and can be installed at ground level. Moreover, it usually uses packing materials readily available and affordable (soil or compost for example). The usual height of the filter bed of an open biofilter is between 1.0 and $1.5 \mathrm{~m}$. Open systems are ideal for applications where space is not a constraint and they are known to be the least expensive solutions for odour control [41].

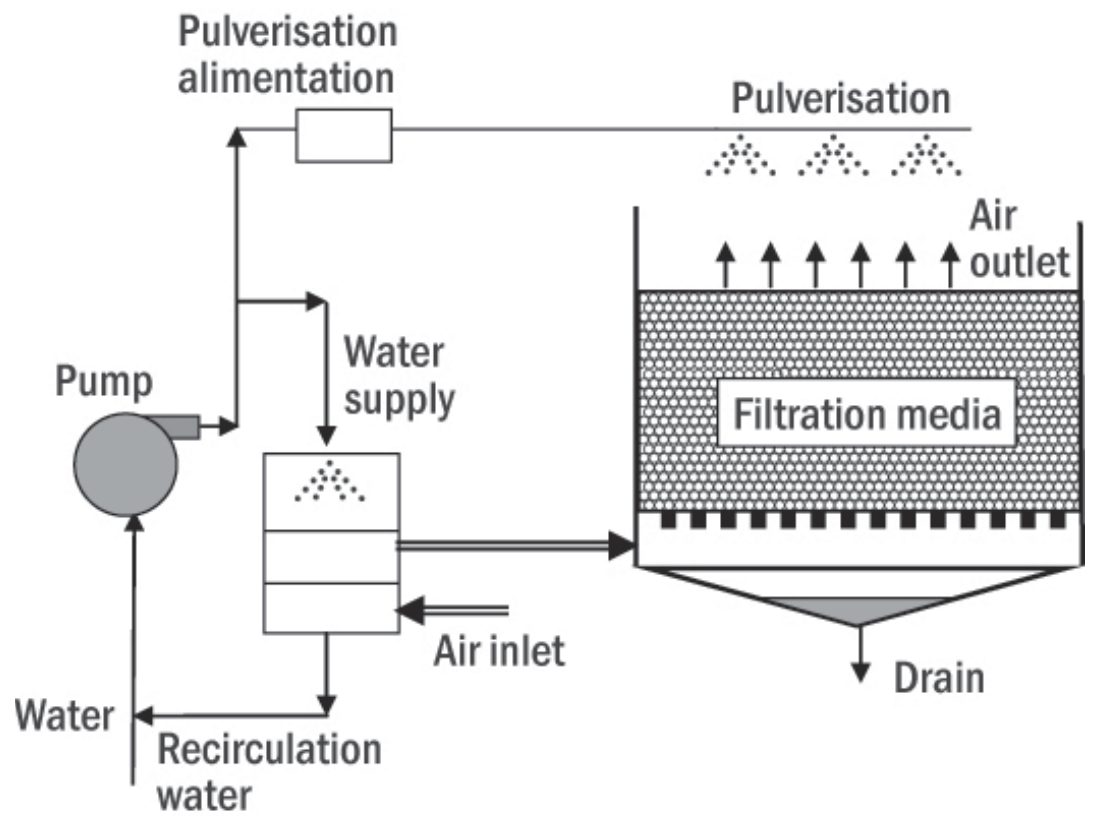

Figure 4. Diagram of an open biofilter system (Adapted from [42])

Closed biofilters (Figure 5) are generally more complex and may have either a circular or rectangular section. These air treatment systems allow a better control of some operating parameters (temperature, moisture, nutrients and $\mathrm{pH}$ ) while being less sensitive to atmospheric conditions. The filter bed used in closed biofilters generally has a height that varies between 1.0 and $1.5 \mathrm{~m}$ and is composed of organic and/or inorganic materials. An air plenum at the inlet and the outlet of the biofilter is generally used for uniform air distribution. For most applications with a closed biofilter, downwards air circulation is more efficient than upward air flow due to a better control of filter bed moisture [47]. 


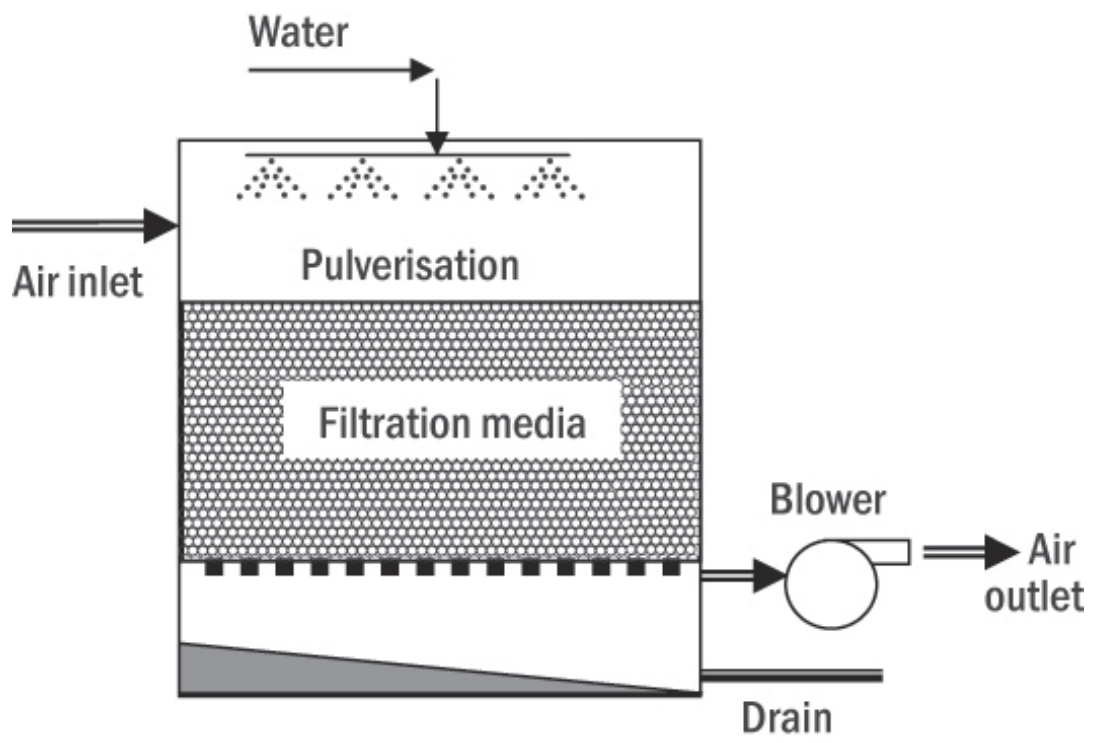

Figure 5. Diagram of a closed biofilter system (adapted from [41])

A study by [49] recommends maintaining the moisture content between 35 and $65 \%$ in the filter material. The average reductions of $\mathrm{H}_{2} \mathrm{~S}$ for low, medium and high relative humidity were 3,72 and $87 \%$, respectively. Under the same conditions, the odour and $\mathrm{NH}_{3}$ reductions were 42,69 and $79 \%$ and 6,49 , and $81 \%$, respectively. The optimal ratio of compost to wood chips recommended by the study for the treatment of air coming from swine buildings is $30 \%$ compost and $70 \%$ wood chips (on a weight basis).

[50] studied a pilot-scale biofilter treating swine ventilation air to determine the optimum operating conditions. The filter bed had a height of $0.5 \mathrm{~m}$ and was built using wood chips of at least $20 \mathrm{~mm}$. The moisture content of the filter bed varied between 64 and $69 \%$. Preliminary tests showed that the installation of a mechanical filter at the air inlet of the biofilter can reduce over $99 \%$ of airborne particles with an odour reduction of $19 \%$. During the experiment, the system achieved a removal efficiency between 73 and $87 \%$ for $\mathrm{NH}_{3}$. When the load of $\mathrm{NH}_{3}$ was increased from 967 to $2057 \mathrm{mg} / \mathrm{h}$ with a maximum volumetric load of $1898 \mathrm{~m}^{3}$ air $/ \mathrm{m}^{3}$ filter $/ \mathrm{h}$, the removal efficiency was reduced by $19 \%$. The study recommended wood chips over $20 \mathrm{~mm}$ for biofilters that are used to treat air emitted from swine production facilities. The maximum recommended volumetric load is $1350 \mathrm{~m}^{3}{ }_{\text {air }} / \mathrm{m}^{3}$ filter $/ \mathrm{h}$ in order to ensure an odour removal efficiency greater than $90 \%$. In summer operating conditions, the size of the biofilter was 0.148 $\mathrm{m}^{2} /$ pig. An efficient humidification system (humidifier at the air inlet and a spraying device above the bedding material) and an adapted air distribution system are determining factors for the design and the operation of treatment systems for high air flow rates.

In another study, [51] compared the effectiveness of two pilot-scale biofilters for the treatment of air from pig barns. The first biofilter used wood chips over $20 \mathrm{~mm}$ and the second one used 
wood chips with dimensions between 10 and $16 \mathrm{~mm}$. The humidity in the filter bed was maintained at $69 \%$ and the volumetric load varied between 769 and $1847 \mathrm{~m}^{3}$ air $/ \mathrm{m}^{3}$ filter $/ \mathrm{h}$ for a trial period of 63 days. Both biofilters reduced the odour in the range of 88 to $95 \%$. The reduction of $\mathrm{NH}_{3}$ was in the range of 64 to $92 \%$ for the first biofilter and 69 to $93 \%$ for the second. $\mathrm{H}_{2} \mathrm{~S}$ was reduced by 9 to $66 \%$ for the first biofilter while the results for the second ranged from an increase of $147 \%$ to a decrease of $51 \%$. The $\mathrm{pH}$ was maintained between 6 and 8 . Investigations show that there is a risk of forming anaerobic zones in the filter bed (second biofilter) which can release reduced sulphur compounds. The study concluded that biofiltration is an interesting technology for the removal of odour and $\mathrm{NH}_{3}$ from the air emitted from swine production facilities.

[52] attempted to combine a strategy of minimum ventilation and biofiltration. A minimum air flow rate of $75 \mathrm{~m}^{3} / \mathrm{h} / \mathrm{pig}$, corresponding to the conditions of summer nights, was established as a reference. The tests were carried out with a biofilter using wood chips with a filter bed height of $27 \mathrm{~cm}$ and an area of $80 \mathrm{~m}^{2}$. The results showed an average removal efficiency of $44 \%$ for ammonia, $58 \%$ for $\mathrm{H}_{2} \mathrm{~S}$ and $54 \%$ for odours. The results are quite modest, but are partially due to reduced volumes of the treated air.

[53] studied the efficiency of biofilters in reducing $\mathrm{NH}_{3}$ emitted from livestock buildings. The aim of the research was to test a filter bed composed of non-expensive organic and inorganic materials in combination with a diverse microbial population (multiculture). The tests were conducted on a bench-scale device with a closed-type reactor with a height of $0.5 \mathrm{~m}$. The packing media was composed of peat (91\% organic), vermiculite and perlite (ratio 3:1:1). In the second series of tests, the filter material was made from peat and polystyrene (3:1 ratio). The results of the study showed that the removal efficiency of $\mathrm{NH}_{3}$ can be very high (99 to $100 \%$ ) under conditions where the inlet concentration is $200 \mathrm{ppmv}$ and flow rates are between 0.03 to $0.06 \mathrm{~m}^{3} / \mathrm{h}$.

A study on a pilot-scale plant by [54] demonstrated the performance of biofilters for odour reduction using different filter materials such as sand, soil, bark and wood mixtures. The reduction of odours analyzed by olfactometry was between 29 and $99.9 \%$ with odour concentrations at the inlet ranging between 143100 and $890000 \mathrm{OU} / \mathrm{m}^{3}$. The study highlighted the presence of leachate resulting from wetting of the filter bed. This fluid plays a very important role in maintaining moisture, but it may also have other effects on the quality of the filter bed, such as washing, accumulation of large amounts of pollutants, interference with the airflow, formation of preferential paths, formation of anaerobic zones and release of $\mathrm{NH}_{3}$ and $\mathrm{H}_{2} \mathrm{~S}$. The study demonstrated the need for further research to clarify these aspects that have a direct influence on the performance and longevity of the biofiltration system.

In response to the questions raised regarding the accumulation of nitrogen compounds in the filter bed due to high inlet concentrations of $\mathrm{NH}_{3}$, a study by Japanese researchers [55] tested the use of a new bacterium (Vibrio alginolyticus), which is able to effectively degrade high concentrations of $\mathrm{NH}_{3}$. The study demonstrated the feasibility of using this marine bacterium for concentrations of ammonia between 120 and 2000 ppmv with removal efficiencies greater than $85 \%$ for more than 60 days of operation. 


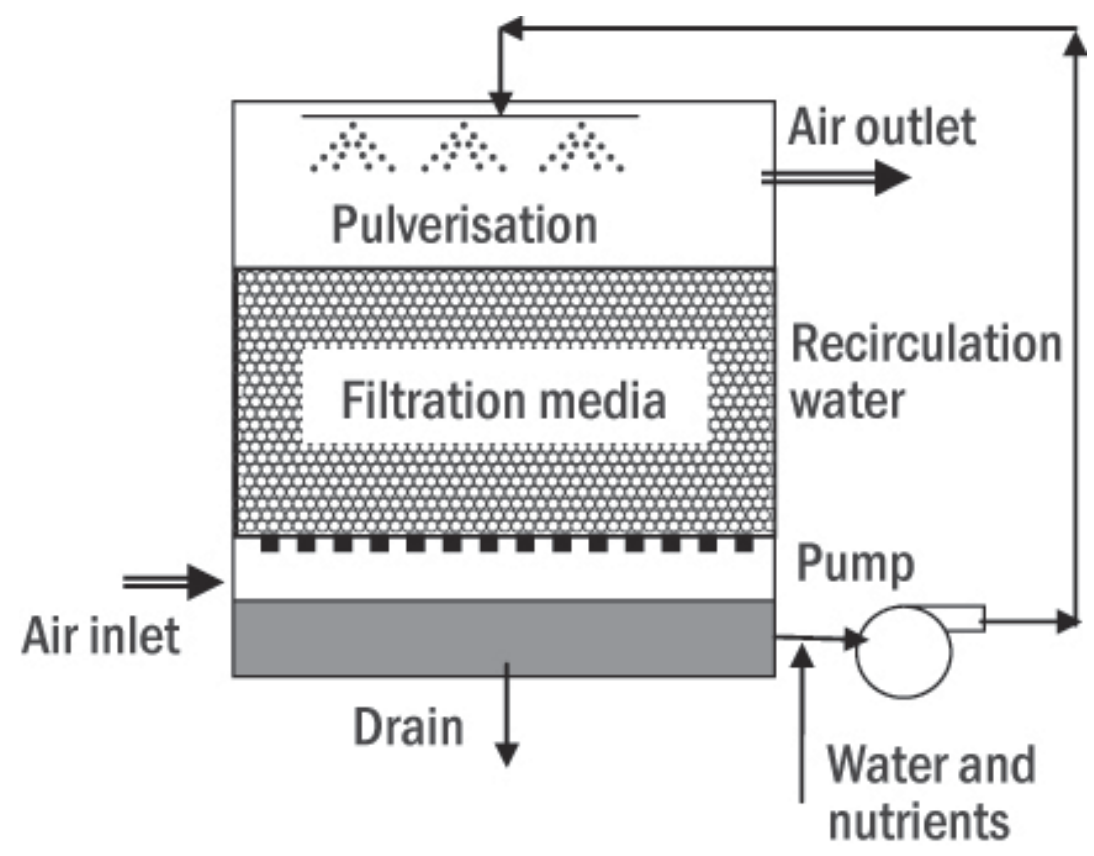

Figure 6. Diagram of a biotrickling filter (adapted from [42])

\subsection{Biotrickling filters}

Contrary to biofilters, biotrickling filters generally use an inorganic packing material with the liquid solution continuously recirculating over the filter bed (Figure 6). This technology offers many advantages: an easy control of key operating parameters (such as temperature, $\mathrm{pH}$, nutrient supply and concentration of toxic compounds), low pressure drops and reduced space requirements by allowing high flow rates.

Air treatment by biotrickling filters is a relatively new technology and the majority of experimental results are from tests carried out with pilot-scale plants [44]. Various filter media, such as lava rock, random plastic packing, structured blocks of plastic and polyurethane foam have been used. The high porosity of these materials provides a minimal pressure drop on the airflow; higher airflow rates are therefore achievable. One of the main characteristics of biotrickling filters is the continuous flow of the liquid on the filter bed. It is therefore possible to improve process control by the addition of nutrients, adjustment of the $\mathrm{pH}$ and the temperature or by removing toxic by-products. For example, in the case of odour reduction and $\mathrm{H}_{2} \mathrm{~S}$ removal, production of sulfuric acid and reduction of $\mathrm{pH}$ and/or accumulation of sodium sulphate are the key controlling parameters. Biotriclickling filters also have other advantages over the other biological treatments in controlling air pollutants [56]: the height of the filter bed, the longer life of the filter media (above 10 years), the ease of control and the ability to treat air containing dust and grease. 
The examples cited by [44] show that these reactors have good removal efficiencies for high concentrations of $\mathrm{H}_{2} \mathrm{~S}$ at low residence times (EBRT). Biotrickling filters seem a good option for the treatment of gases with high concentrations of $\mathrm{H}_{2} \mathrm{~S}$ and possibly for other sulfur compounds. Experiments on industrial applications have shown the potential of biofilters and biotrickling filters for the simultaneous removal of odour, $\mathrm{H}_{2} \mathrm{~S}$ and VOCs. From a total of eight cases of biotrickling filters used for the removal of $\mathrm{H}_{2} \mathrm{~S}$ and for inlet concentrations of 1 to 1000 $\mathrm{mg} / \mathrm{m}^{3}$, the reduction efficiencies varied from 95 to $99 \%$. For the reduction of odours, the efficiencies obtained were 65 to $99 \%$.

Biotrickling filters should be inoculated with a variety of microorganisms, since inorganic filter beds generally do not contain bacteria. The addition of nutrients can also become a tool for optimizing the performance of the reactor. The nutrient requirements depend on the type of pollutant to be treated, its concentration, the pollutant loading and the operating conditions of the reactor. However, excess nutrients can lead to an overproduction of biomass and eventually clog the reactor.

A cross-flow biotrickling filter was developed at the IRDA for the treatment of swine ventilation air. Pilot-scale tests were carried out with 6 units treating air from chambers housing 4 grower-finisher pigs. After a start-up phase between 9 and 20 days, the system was able to reduce emissions of $\mathrm{NH}_{3}$ and odours by up to 68 and $82 \%$ respectively. Different operating conditions were tested (air residence time, liquid flow rate and type of packing material), but very little effect was observed since the system was probably over-sized. The biotrickling filters had no significant effect on $\mathrm{CO}_{2}$ and $\mathrm{CH}_{4}$ emissions.

\subsection{Bioscrubbers}

In a bioscrubber, each step of the treatment process is separate: the pollutants are first transferred to a liquid solution in an absorption unit and then the washing liquid is regenerated in a biological reactor which generally resembles an activated sludge reactor (Figure 7). Similar to the biotrickling filter, the operating conditions can easily be controlled in a bioscrubber and it is possible to optimize both the absorption and biodegradation of pollutants. [43] reported several types of absorbers such as the packed tower, the wet cyclone, the spray tower and the venturi scrubber.

The flow of air and water can either be counter-current, co-current or cross-current. The air velocity can vary between $1.5 \mathrm{~m} / \mathrm{s}$ and $20 \mathrm{~m} / \mathrm{s}$ in a spray tower, it can reach $25 \mathrm{~m} / \mathrm{s}$ for a wet cyclone and between 40 and $50 \mathrm{~m} / \mathrm{s}$ for a venturi. Bioscrubbers have the same space, flexibility and control than biotrickling filter, but they are only suitable for the treatment of highly water soluble compounds (Henry's coefficient below 0.01). Bioscrubbers have thereby increased the scope of application for the biological treatment of waste gases. The greatest advantage of bioscrubbers compared to biofilters and biotrickling filters is the ability to produce and maintain large amount of active microbial mass in smaller units. On the other hand, [57] considers that bioscrubbers and biotrickling filters present greater construction and operation complexity. 


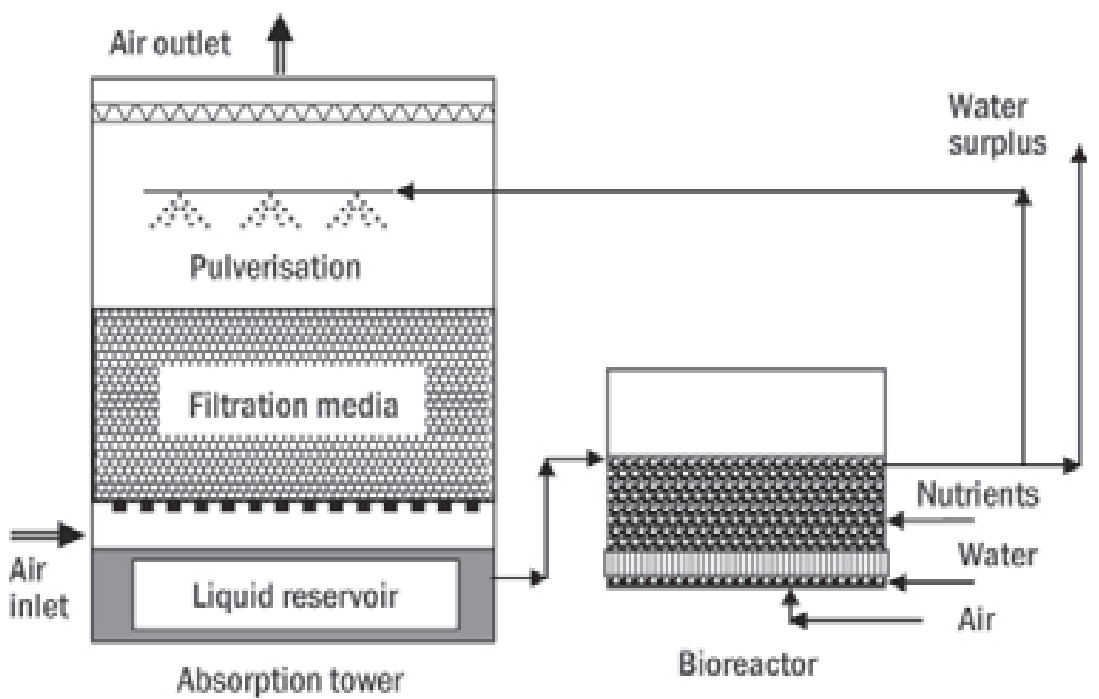

Figure 7. Diagram of a bioscrubber (adapted from [42])

[43] concluded that bioscrubbers offer the greatest efficiencies for the removal of $\mathrm{H}_{2} \mathrm{~S}, \mathrm{NH}_{3}$ and organic sulphur compounds. The performance analysis of bioscrubbers used in the industry for $\mathrm{H}_{2} \mathrm{~S}$ removal showed efficiencies over $98 \%$ for low, medium and high inlet concentrations (between 0 and $75 \mathrm{mg} / \mathrm{m}^{3}, 2000 \mathrm{mg} / \mathrm{m}^{3}$ and between 10000 and $15000 \mathrm{mg} / \mathrm{m}^{3}$ respectively). The results cited for the reduction of odours show an efficiency of $80 \%$ for the reduction of organic sulfides with inlet concentrations between 4000 and $22000 \mathrm{OU}$.

There are many technologies available for the reduction of air contaminants and odours using biological reactions. Several systems have configurations that are similar to each other though different in terms of operating conditions. The difficulty of using one of the existing technologies for the treatment of air comes from the specific constraints of each application. Livestock buildings in general are characterized by a very large number of parameters that influence the application of air treatment.

Biofiltration has been the subject of many scientific publications and several units are currently installed throughout the world. Its efficiency has been demonstrated for reducing odours and to a lesser extent, for the reduction of $\mathrm{NH}_{3}$ and $\mathrm{H}_{2} \mathrm{~S}$ emitted from barns. However, despite the advantage of being simple, the use of biofilters in livestock buildings is limited by several problems such as the accumulation of pollutants, the potential for clogging, the high pressure losses and the relatively rapid degradation of the filter bed. On the other hand, even if biotrickling filters and bioscrubbers have better features compared to biofiltration (e.g. rapid response to changes in operating conditions and longer life time), experimental research on these two technologies has just started and only specific solutions for specific applications and partial results are available. There are not many experimental studies on full-scale systems. 
[45] highlighted that the technologies with the greatest potential for reducing the contaminants emitted from livestock buildings should, in all likelihood, come from the combination of different treatment systems. A combination of an air scrubber and a biotrickling filter or a combination of a biofilter and a biotrickling filter could provide greater capabilities than each technology used individually. However, there is no information in the literature on the efficiency of these different combinations of technologies.

\section{Conclusion}

This chapter outlined the importance of biodegradation associated with modern manure management practices. Depending on the type of management strategy and the production stage, both aerobic and anaerobic conditions can prevail, providing a wide range of emissions. The second part of the chapter explored the different technologies where biodegradation can be used to treat both the manure and the gaseous emissions. Biological treatment systems generally provide good removal efficiencies at relatively low costs and are well adapted to the agricultural sector.

\section{Author details}

Matthieu Girard*, Joahnn H. Palacios, Martin Belzile, Stéphane Godbout and Frédéric Pelletier

*Address all correspondence to: matthieu.girard@irda.qc.ca

Research and Development Institute for the Agri-Environment (IRDA), Québec (Qc), Canada

\section{References}

[1] Godbout, S. and Trudelle, M. 2002. Évaluation des performances techniques des séparateurs mécaniques à lisier et de leur rapport efficacité/coût. Final Report, IRDA, 84 pages.

[2] Andreottola, G., Bortone, G., and Tilche, A. 1997. Experimental validation of a simulation and design model for nitrogen removal in sequencing batch reactor. Water, Science and Technology, 35(1): 113-120.

[3] Boursier, H., Béline, F., and Paul, E. 2005. Piggery wastewater characterisation for biological nitrogen removal process design. Bioresource Technology, 96: 351-358. 
[4] Aubry, G. 2008. Étude du comportement de l'azote dans un biofiltre à lit ruisselant traitant du lisier de porc. Ph.D. thesis, Department of Civil Engineering, Laval University, Quebec City, Qc. Canada.

[5] Metcalf and Eddy. 2003. Wastewater engineering: treatment and reuse - 4th edition. McGraw-Hill, New-York.

[6] Henze, M., Harremoës, P., la Cour Jansen, J., and Arvin, E. 2002. Wastewater treatment: biological and chemical processes - 3rd edition. Springer, New York, United States.

[7] Schiffman, S.S., J.L. Bennett, and J.H. Raymer. 2001. Quantification of odors and odorants from swine operations in North Carolina. Agric. Forest Meteor. 108(3): 213-240.

[8] Møller, H.B., S.G. Sommer and B.K. Ahring. 2002. Separation e " ciency and particle size distribution in relation to manure type and storage conditions. Bioresource Technology 85, 189-196.

[9] Natural Resources Conservation Service. 2007. Manure chemistry - Nitrogen, Phosphorus, \& Carbon. Manure management information sheet, number 7.

[10] Hamilton, D. W. 2009. Anaerobic Digestion of Animal Manures: Understanding the Basic Processes. Oklahoma Cooperative Extension Service. BAE-1747.

[11] Godbout, S., L. Hamelin, J. H. Palacios, F. Pelletier, S.P. Lemay and F. Pouliot. 2011. État de référence des émissions gazeuses et odorantes provenant des bâtiments porcins québécois. Final report. IRDA. 53 pages.

[12] Marquis, A. and P. Marchal. 1998. Qualité de l'atmosphère à proximité des bâtiments d'élevage. Cahiers d'études et de recherches francophones - Agricultures. 7(5): 377-385.

[13] Hamelin, L., M. Wesnæs, H. Wenzel and B.M. Petersen. 2010. Life cycle assessment of slurry management technologies II - emphasis on biogas production. Danish Ministry of the Environment, Environmental Protection Agency. http://www2.mst.dk/ udgiv/publications /2010/978-87-92668-03-5/pdf/978-87-92668-04-2.pdf. Accessed January 30, 2013.

[14] IPCC. 2007. Fourth Assessment Report (AR4) by Working Group 1 (WG1), Chapter 2 "Changes in Atmospheric Constituents and in Radiative Forcing".

[15] EPA. Environmental Protection Agency. 2010. Particulate matter. http:// www.epa.gov/pm/. Accessed January 30, 2013.

[16] Cambra-López, M., A.J.A. Aarnink, Y. Zhao, S. Calvet and A.G. Torres. 2010. Airborne particulate matter from livestock production systems: A review of an air pollution problem. Environmental Pollution, 158: 1-17. 
[17] Chadwick, D.R., Sneath, R.W., Phillips, V.R., and Pain, B.F. 1999. A UK inventory of nitrous oxide emissions from farmed livestock. Atmospheric Environment, 33: 3345-3354.

[18] Velthof, G.L., Nelemans, J.A., Oenema, O., and Kuikman, P.J. 2005. Gaseous nitrogen and carbon losses from pig manure derived from different diets. Journal of Environmental Quality, 34: 698-706.

[19] Chantigny, M.H., MacDonald, J.D., Beaupré, C., Rochette, P., Angers, D.A., Massé, D.I., and Parent, L.-É. 2009. Ammonia volatilization following surface application of raw and treated liquid swine manure. Nutrient Cycling in Agroecosystems, 85(3), p. 275-286.

[20] Perron, M-H. 2010. Disponibilité de l'azote de biosolides de traitement de lisier de porc et de deux boues de papetière et émissions de N2O consécutives à leur épandage au champ. Master thesis. Laval University, Québec, Canada. 138 pages.

[21] Zhang, Z., and Zhu, J. 2006. Characteristics of solids, BOD5 and VFAs in liquid swine manure treated by short-term low-intensity aeration for long-term storage. Bioresource Technology, 97: 140-149.

[22] BAPE. 2003. L'état de la situation de la production porcine au Québec. Rapport d'enquête et d'audience publique du Bureau d'audiences publiques sur l'environnement, ISBN: 2-550-41393-8.

[23] Westerman, P.W., Bicudo, J.R., and Kantardjieff, A. 2000. Upflow biological aerated filters for the treatment of flushed swine manure. Bioresource Technology, 74: 181-190.

[24] Lanoue, M. 1998. Traitement du lisier de porc par procédé de biofiltration aérobie. M.Sc. thesis, Department of Chemical Engineering, Université de Sherbrooke, Sherbrooke, Qc. Canada.

[25] Westerman, P.W. and Arogo, J. 2004. Ekokan biofiltration technology performance verification. Available from the North Carolina State University's College of Agriculture and Life Sciences: http://www.cals.ncsu.edu/waste_mgt/smithfield_ projects/ phase1report04/A.6EKOKAN\%20final\%20.pdf. [Accessed in January 2013].

[26] Sommer, S.G., Mathanpaal, G., and Dass, G.T. 2005. A simple biofilter for treatment of pig slurry in Malaysia. Environmental Technology, 26: 303-312.

[27] Buelna, G. 2000. Biofilter for purification of waste waters and method therefore. United States Patent Number 6,100,081.

[28] Dubé, R. 1997. Traitement du lisier de porc par biofiltration sur milieu organique : influence de l'aération. M.Sc. thesis, Department of Civil Engineering, Laval University, Quebec, Qc. Canada. 
[29] Aubry, G., Lessard, P., Gilbert, Y., Le Bihan, Y., and Buelna, G. 2006. Nitrogen behaviour in a trickling biofilter treating pig manure, Water Science and Technology, IWA Conference BIOFILMS Systems VI, Amsterdam.

[30] Garzón-Zúñiga, M., Lessard, P., Aubry, G., and Buelna, G. 2005. Nitrogen elimination mechanisms in an organic media aerated biofilter treating pig manure. Environmental Technology, 26: 361-371.

[31] Garzón-Zúñiga, M., Lessard, P., Aubry, G., and Buelna, G. 2007. Aeration effect on the efficiency of swine manure treatment in a trickling filter packed with organic materials. Water, Science and Technology, 55(10): 135-143.

[32] Ros, M., García, C., and Hernández, T. 2005. A full-scale study of treatment of pig slurry by composting: kinetic changes in chemical and microbial properties. Waste Management, 26: 1108-1118.

[33] Huang, G.F., Wong, J.W.C., Wu, Q.T. and Nagar, B.B. 2004, Effect of C/N on composting of pig manure with sawdust. Waste Management, 24: 805-813.

[34] Zhu, N. 2007. Effect of low initial C/N ratio on aerobic composting of swine manure with rice straw. Bioresource Technology, 98: 9-13.

[35] Hassouna, M., Espagnol, S., Robin, P., Paillat J-M., Levasseur, P. and Li, Y. 2008. Monitoring $\mathrm{NH} 3, \mathrm{~N} 2 \mathrm{O}, \mathrm{CO} 2$ and $\mathrm{CH} 4$ emissions during pig solid manure storage effect of turning. Compost Science \& Utilization. 16(4): 267-274.

[36] Fukumoto, Y., Suzuki, K., Osada, T., Kuroda, K., Hanajima, D., Yasuda, T., and Haga, K. 2006. Reduction of nitrous oxide emission from pig manure composting by addition of nitrite-oxidizing bacteria. Environmental Science and Technology, 40: 6787-6791.

[37] Juteau, P. 2006. Review of the use of aerobic thermophilic bioprocesses for the treatment of swine waste, Livestock Science, 102: 187- 196.

[38] Ortenblad, H. 2000. The use of digested slurry within agriculture. Available from: http://homepage2.nifty.com/biogas/cnt/refdoc/whrefdoc/d9manu.pdf [accessed in January 2013.]

[39] Ricard, M.-A., V. Drolet, A. Coulibaly, C.B. Laflamme et al. 2010. Développer un cadre d'analyse et identifier l'intérêt technico-économique de produire du biogaz à la ferme dans un contexte québécois. Report produced by the Centre de développement du porc du Québec (CDPQ), ISBN 978-2-922276-35-0, 110 pages.

[40] Deshusses, M., Z. Shareefdeen. 2005. Modeling of biofilter and biotrickling filters for odour and VOC control applications. Biotechnology for odour and air pollution control. ed. Z. Shareefdeen and A. Singh. Springer. Verlag, Berlin, Heidelberg.

[41] Devinny, J.S., M.A. Deshusses, T.S. Webster. 1999. Biofiltration for air pollution control. Lewis Publishers. Washington, DC, USA. 
[42] Revah, S. and J.M. Morgan-Sagastume. 2005. Methods of odor and VOC control. Biotechnology for odour and air pollution control. ed. Z. Shareefdeen and A. Singh. Springer. Verlag, Berlin, Heidelberg.

[43] Singh, A., Z. Shareefdeen and O.P. Ward. 2005. Bioscrubber technology. Biotechnology for odour and air pollution control. ed. Z. Shareefdeen and A. Singh. Springer. Verlag, Berlin, Heidelberg.

[44] Iranpour, R., H.H.J. Cox, M.A. Deshusses and E.D. Schroeder. 2005. Literature review of air pollution control biofilters and biotrickling filters for odor and volatile organic compound removal. Environmental Progress. 24 (3).

[45] Lemay S.P., M. Martel, M. Belzile, D. Zegan, J. Feddes, S. Godbout, F. Pelletier. 2009. A systematic literature review to identify an air contaminant removal technology for swine barn exhaust air. Written for presentation at the CSBE/SCGAB 2009 Annual Conference Rodd's Brudenell River Resort, Prince Edward Island, Canada. 12-15 July 2009.

[46] Godbout S., S.P. Lemay, F. Pelletier, M. Belzile, J.P. Larouche, L.D. Tamini, J. H. Palacios and D. Zegan. 2010. Réduction des émissions gazeuses et odorantes aux bâtiments porcins : techniques simples et efficaces applicables à la ferme. Final Report. IRDA. 143p.

[47] Godbout, S., F. Pelletier, J.P. Larouche, M. Belzile, J.J.R. Feddes, S. Fournel, S.P. Lemay and J.H. Palacios. 2012. Greenhouse Gas Emissions from Non-Cattle Confinement Buildings: Monitoring, Emission Factors and Mitigation. Greenhouse Gases Emission, Measurement and Management, Guoxiang Liu (Ed.), ISBN: 978-953-51-0323-3, InTech, DOI: 10.5772/31948.

[48] Delhoménie, M.-C, and Heitz, M. 2005. Biofiltration of air: a review. Critical Reviews in Biotechnology, 25(1-2): 53-72.

[49] Nicolai, R.E. and Janni, K.A. 2001. Biofilter media mixture ratio of wood chips and compost treating swine odors. Dept of Biosystems and Agricultural Engineering, University of Minnesota, USA.

[50] Sheridan, B. A., T. P. Curran and V. A. Dodd. 2002. Assessment of the influence of media particle size on the biofiltration of odorous exhaust ventilation air from a piggery facility. Bioresource Technology. 84: 129-143.

[51] Sheridan, B. A., T. Curran, V. Dodd and J. Colligan. 2002. Biofiltration of odour and ammonia from a pig unit - A pilot-scale study. Biosystems Engineering. 82 (4): 441-453.

[52] Hoff, S. J. and J. D. Harmon. 2006. Biofiltration of the critical minimum ventilation exhaust air. Workshop on Agricultural Air Quality. Washington, D.C., USA. 
[53] Kalingan, A. E., C. M. Liao, J. W. Chen and S. C. Chen. 2004. Microbial Degradation of Livestock -Generated Ammonia Using Biofilters at Typical Ambient Temperatures. Journal of Environmental Science and Health. B 39 (1): 185-198.

[54] Luo, J. 2001. A pilot-scale study on biofilters for controlling animal rendering process odours. Water Science and Technology. 44 (9): 277-285.

[55] Kim, N. J., Y. Sugano, M. Hirai and M. Shoda. 2000. Removal of a high load of ammonia gas by a marine bacterium, Vibrio Alginolyticus. Journal of Bioscience and Bioengineering. 90 (4): 410-415.

[56] Deshusses, M. A. and D. Gabriel. 2005. Biotrickling filter technology. Biotechnology for odour and air pollution control. ed. Z. Shareefdeen and A. Singh. Springer. Verlag, Berlin, Heidelberg.

[57] Kraakman, A. 2005. Biotrickling and Bioscrubber Applications to control odour and air pollutants. Biotechnology for odour and air pollution control. ed. Z. Shareefdeen and A. Singh. Springer. Verlag, Berlin, Heidelberg. 